\title{
Zn-Fe and Zn-Fe-Y Cementation Coatings for Enhancing Corrosion Resistance of Steel
}

\author{
Sirong $\mathrm{Yu}^{*}, \mathrm{Li} \mathrm{Liu}$ \\ College of Mechanical and Electronic Engineering. China University of Petroleum (East China), \\ Qingdao 266580, P.R China \\ *E-mail: liuli1212006@outlook.com
}

doi: $10.20964 / 2017.06 .84$

Received: 22 March 2017 / Accepted: 18 April 2017 / Published: 12 May 2017

This work aims to enhace the corrosion resistance of medium carbon steel 45 . $\mathrm{Zn}$-Fe coatings on steel 45 were prepared at different temperatures $\left(380^{\circ} \mathrm{C}, 390^{\circ} \mathrm{C}, 400^{\circ} \mathrm{C}\right.$ and $\left.410^{\circ} \mathrm{C}\right)$ by pack cementation process. The microstructure, formation mechanism and corrosion behavior of the $\mathrm{Zn}$-Fe coatings were investigated. The $\mathrm{Zn}-\mathrm{Fe}$ coating possessed a two-layered structure consisting of a thin diffusion layer and a thick outer layer. The coating thickness increased with the increase of the temperature. $\mathrm{Zn}-\mathrm{Fe}-\mathrm{Y}$ coating on steel 45 was prepared by the pack cementation process at $390^{\circ} \mathrm{C}$. The effect of $\mathrm{Y}$ addition on the microstructure and corrosion behavior of the $\mathrm{Zn}-\mathrm{Fe}$ coating was studied. The structure of the $\mathrm{Zn}-\mathrm{Fe}-\mathrm{Y}$ coating was similar to that of the Zn-Fe coating. The coating thickness increased with the addition of $\mathrm{Y}$. The activation energies for the formation of the $\mathrm{Zn}-\mathrm{Fe}$ and the $\mathrm{Zn}-\mathrm{Fe}-\mathrm{Y}$ coatings were $82.31 \mathrm{~kJ} / \mathrm{mol}$ and $81.12 \mathrm{~kJ} / \mathrm{mol}$, respectively. The corrosion resistance was measured by the immersion test and polarization test. The results showed that the corrosion resistance of the $\mathrm{Zn}$-Fe coating firstly increased and then decreased with the increase of temperature. The $\mathrm{Zn}-\mathrm{Fe}-\mathrm{Y}$ coating had better corrosion resistance than the $\mathrm{Zn}-\mathrm{Fe}$ coating.

Keywords: Coating; Microstructure; $\mathrm{Y}_{2} \mathrm{O}_{3}$; Activation energy; Corrosion resistance.

\section{$\underline{\text { FULL TEXT }}$}

(C) 2017 The Authors. Published by ESG (www.electrochemsci.org). This article is an open access article distributed under the terms and conditions of the Creative Commons Attribution license (http://creativecommons.org/licenses/by/4.0/). 